\title{
Electron microscopy of serum of healthy hepatitis B antigen carriers
}

\author{
I. L. WOOLF, D. M. JONES, E. TAPP, AND I. W. DYMOCK \\ From the Departments of Medicine, Bacteriology, and Pathology, University Hospital of South Manchester
}

SYNOPSIS The sera of 36 blood donors who are established $\mathrm{HB}_{\mathrm{s}} \mathrm{Ag}$ carriers were examined with the electron microscope. The findings were correlated with the histological and electronoptic appearances of the liver and the titre and subtype of the antigen. Antigen-antibody complexes could not be detected. Dane particles constituted $2 \%$ or more of the total particle count in five of the 36 sera, including three sera from five carriers with chronic aggressive hepatitis and two sera from 11 carriers with chronic persistent hepatitis. In sera from carriers with normal histology or the minimal histological lesion of focal parenchymal necrosis they were detected very infrequently or not at all. Three biopsies revealed intranuclear inclusions when examined electronoptically and the corresponding sera all contained $>2 \%$ Dane particles. Where $>2 \%$ Dane particles were seen the antigen titre tended to be high. The predominant subtype was ad. There was no correlation between the number of Dane particles and the antigen subtype nor between subtype and histology.

The morphological variation of the hepatitis $B$ antigen $\left(\mathrm{HB}_{\mathbf{s}} \mathrm{Ag}\right)$ as seen under the electron microscope is now well known (Almeida, 1972) but the significance of this variation is still not fully established. The three particle types which have been described have been reported to be present in different proportions in different forms of hepatitis (Wright, 1970) and Dane particles have been reported to be absent in the serum of healthy carriers (Nielsen, Nielsen, and Elling, 1973).

The present study was undertaken to investigate the morphological variations in $\mathrm{HB}_{\mathbf{s}} \mathrm{Ag}$ in a group of established carriers. These have been correlated with the histological and electronoptic appearances of the liver, with the antigen titre, and with the antigen subtype.

\section{Patients and Methods}

The subjects were 36 blood donors, found to be $\mathrm{HB}_{\mathrm{S}} \mathrm{Ag}$ positive using the technique of immunoelectroosmophoresis and who had remained positive for at least six months. Serum samples were obtained at the time of liver biopsy and stored at $-20^{\circ} \mathrm{C}$. They were examined by direct and immune electron

'Correspondence to: Dr I. W. Dymock, Department of Medicine, University Hospital of South Manchester, Withington Hospital, Manchester M20 8LR, England.

Received for publication 3 December 1974. microscopy, using, for the latter, three different antisera.

\section{Electron Microscopy of Serum}

An $0.2 \mathrm{ml}$ volume of serum was examined and for immune electron microscopy $0.1 \mathrm{ml}$ antiserum was added initially and incubated at $4^{\circ} \mathrm{C}$ overnight. The sample was diluted with $2.0 \mathrm{ml}$ phosphate-buffered saline before centrifugation $(55000 \times g)$ for one hour. The resulting pellets were negatively stained with $2 \%$ phosphotungstic acid (pH 6) and examined in an AEI EM 801 electron microscope. In the samples to which antiserum had been added, the relative proportions of the three particle types in the resulting aggregates was assessed by photographing three separate areas of the grid. At least 200 particles were counted.

\section{Electron Microscopy of the Liver}

In 18 biopsies, part of the specimen was fixed in $4 \%$ glutaraldehyde and processed for electron microscopy using standard techniques. Ultrathin sections were scanned at a magnification of 63000 and at least 20 cells examined from each specimen.

ANTIGEN TITRE AND SUBTYPE

The antigen titre was estimated by testing sera in dilution by immunoelectroosmophoresis. The anti- 
gen subtypes were determined, using the technique of haemagglutination inhibition, by Mr R Hopkins of the National Blood Transfusion Service, Edinburgh.

\section{Results}

ELECTRON MICROSCOPY OF SERUM

Electron microscopy confirmed the presence of $\mathrm{HB}_{\mathrm{s}} \mathrm{Ag}$ in the serum of every carrier, but aggregation of particles into complexes was not observed without the prior addition of antiserum. The use of different antisera did not significantly alter the composition of the aggregates produced in any particular serum, although in six sera aggregates did not form when the human antiserum, which was of comparatively low titre, was employed.

In all the sera the predominant morphological type was the $20 \mathrm{~nm}$ sphere, which never constituted less than $70 \%$ of the total number of particles. The percentage of tubules ranged from 16 in one instance to less than 1 and in five sera no tubules were detected. Dane particles were detected without difficulty in five sera, and ranged from 2 to $13 \%$ of the total number of particles. They were also detected after prolonged searching in a further six sera, in numbers which never constituted more than $0.5 \%$ of the total particle count. In the remainder of the sera, despite prolonged searching, Dane particles could not be detected.

Examination of sera taken at intervals over a period of months demonstrated that the distribution of particle types and the antigen titre were consistent for each carrier.

\section{HISTOLOGICAL FINDINGS}

The histological appearances of the liver in all but two of these carriers have been previously described in detail (Woolf, Boyes, Jones, Whittaker, Tapp, MacSween, Renton, Stratton, and Dymock, 1974).

The histological findings and their relationship to the electron microscopy of the serum are shown in table I. Of the five sera which contained $>2 \%$ Dane particles, three were derived from carriers with chronic aggressive hepatitis and two from carriers with chronic persistent hepatitis. The proportion of the carriers with chronic aggressive hepatitis who had Dane particles in the serum was significantly greater than was found in the other two groups ( $P$ $<0.01)$. There was no correlation between the number of tubules and the liver histology.

\section{ELECTRON MICROSCOPY OF THE LIVER (FIG)}

Intranuclear particles measuring $20 \mathrm{~nm}$ in diameter were found with ease in most nuclei in three of the 18 biopsies. Two of these had chronic persistent hepatitis and the third a chronic aggressive hepatitis. In

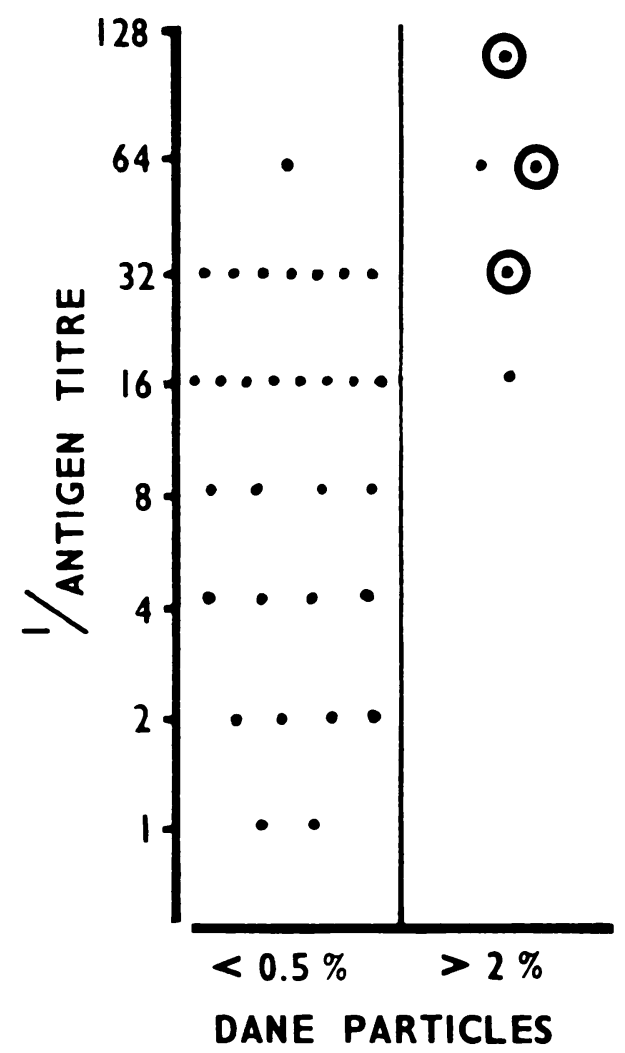

Fig Relation of the reciprocals of $\mathrm{HB}_{\delta} \mathrm{Ag}$ titres

to the detection of Dane particles and intranuclear particles. The open circles represent the latter.

\begin{tabular}{lccc}
\hline Histological Diagnosis & $\begin{array}{l}\text { Number } \\
\text { of } \\
\text { Carriers }\end{array}$ & $\begin{array}{l}\text { Frequency of } \\
\text { Dane Particles } \\
(>2 \%)\end{array}$ & $\begin{array}{c}\text { Subtype } \\
\text { Intranuclear } \\
\text { Particles }\end{array}$ \\
\hline Cirrhosis & 1 & 0 & 0 \\
Chronic aggressive hepatitis & 5 & 3 & 0 \\
Chronic persistent hepatitis & 11 & 2 & 0 \\
Focal necrosis & 13 & 0 & 0 \\
Normal or incidental lesions & 6 & 0 & 0 \\
\hline
\end{tabular}

Table Correlations of Dane particles, intranuclear particles, and subtype with liver histology 
all three, frequent Dane particles were present in the serum. In a minority of the other biopsies small numbers of particles were seen in occasional nuclei. No spherical or tubular forms were found in the cytoplasm in any of the specimens.

\section{ANTIGEN TITRE (FIG)}

Titres varied between antigen detectable only in undiluted serum to those in which it was detected at a dilution of $1 / 128$. There was no correlation between the antigen titre and the histological findings. The five patients with chronic aggressive hepatitis had titres ranging from $1 / 4$ to $1 / 64$. Where Dane particles were seen the titre was always in excess of $1 / 16$.

ANTIGEN SUBTYPE (TABLE)

The antigens of 30 donors were ad and six were ay. Two of those with subtype ay had chronic aggressive hepatitis, but there was no correlation with liver histology. The subtype could not be correlated with the finding of Dane particles either.

\section{Discussion}

In this study of healthy carriers, antigen-antibody complexes were not detected without the prior addition of antiserum and Dane particles were found easily in only a minority of the sera. Although it has been suggested (Field and Cossart, 1971) that the different types of hepatitis B antigen particle may differ antigenically, in those sera that were examined following the addition of each of the three antisera, no differences in the relative proportions of the three particle types were observed. In those sera where Dane particles were seen the other two types of particle were present in the same clumps. It seems unlikely, therefore, that the failure to detect Dane particles in the majority of the sera was due to antigenic differences between the $20 \mathrm{~nm}$ forms and the surface protein of the Dane particle.

The predominant subtype was ad, probably reflecting the fact that the majority of the donors in the survey were born and bred in Great Britain (PonsRomero, Heathcote, and Sherlock, 1974). Dane particles were seen with both subtypes and both were associated with a spectrum of histological changes in agreement with other surveys (Gordon, Berberian, Stevenson, and Redeker, 1972; PonsRomero et al, 1974).

Where Dane particles were frequent the titre of $\mathrm{HB}_{\mathrm{s}} \mathrm{Ag}$ in the serum tended to be high which is in accord with the findings of Jokelainen, Krohn, Finlayson, and Prince (1973). Of greater interest, however, is the apparent relationship between the presence of Dane particles in the serum and the more florid histological abnormalities.

In three biopsies intranuclear inclusions were seen electronoptically which resembled the $20 \mathrm{~nm}$ particles first described in the hepatocyte nuclei of immunosuppressed $\mathrm{HB}_{\mathrm{s}} \mathrm{Ag}$-positive patients with lymphoproliferative disorders by Nowoslawski, Madalinski, Brzosko, and Krawczynski (1970). The corresponding sera all contained numerous Dane particles and there is increasing evidence that these intranuclear inclusions represent the core of the Dane particle (Ricci, De Bac, Turbessi, and Caramia, 1973). It is possible that the presence of core particles within the hepatocyte nuclei and of Dane particles in the serum is a reflection of impaired immunity to the hepatitis $B$ virus, and that such impairment predisposes to chronic liver disease.

We are indebted to Dr F. Stratton, Dr L. D. Wadsworth, and Dr P. H. Renton of the National Blood Transfusion Service, Manchester, who referred the carriers; to Dr J. S. Whittaker for help in the interpretation of the liver biopsies, and to $\mathrm{Dr}$ J. O'H Tobin for the use of the electron microscope. Mrs J. E. Robinson, Mrs C. Anfield, and Mr A. Curry provided valuable technical assistance.

It is again a pleasure to acknowledge the encouragement and advice of Professor J. M. Evanson.

\section{References}

Almeida, J. D. (1972). Individual morphological variations seen in Australia antigen positive sera. Amer. J. Dis. Child., 123, 303-309.

Field, A. M., and Cossart, Y. E. (1971). Specificity of Au antibodies. Lancet, 2, 91 .

Gordon, I., Berberian, M., Stevenson, D., and Redeker, A. G. (1972). Distribution of hepatitis $\mathbf{B}$ antigenic determinants in differen forms of viral hepatitis. J. infect. Dis., 126, 569-573.

Jokelainen, P. T., Krohn, K., Finlayson, N. D. C., and Prince, A. M (1973). Serum 'virus-like' particles in chronic hepatitis and cirrhosis: relation to immunological tests for hepatitis $B$ antigen. Gastroenterology, 65, 796-801.

Nielsen, J. O., Nielsen, M. H., and Elling, P. (1973). Differential distribution of Australia-antigen-associated particles in patients with liver diseases and normal carriers. New Engl. J. Med., 288, 484-487.

Nowoslawski, A, Brzosko, W. J., Madalinski, K., and Krawczynski, K. (1970). Cellular localization of Australia antigen in the live of patients with lymphoproliferative disorders. Lancet, 1, 494498.

Pons-Romero, F., Heathcote, J., and Sherlock, S. (1974). The epidemiological importance of 'ay' and 'ad' subtypes of the HB-Ag. Gut, 15, 733-736.

Ricci, G., De Bac, C., Turbessi, G., and Caramia, F. (1973). Intranuclear virus-like particles and cytoplasmic $\mathrm{HB} \mathrm{Ag}$ in chronic hepatitis. New Engl.J. Med., 289, 1144-1145.

Woolf, I. L., Boyes, B. E., Jones, D. M., Whittaker, J. S., Tapp, E., MacSween, R. N.M., Renton, P.H., Stratton, F., and Dymock, I. W. (1974). Asymptomatic liver disease in hepatitis B antigen carriers. J. clin. Path., 27, 348-352.

Wright, R. (1970). The Australia antigen in chronic active hepatitis lox Sang. (Basel), 19, 320-326. 